dissociation of the shocks which are produced under the influence of cold, all these seem arguments in favour of the theory which considers muscular contraction as the result of very frequent shocks; but the complexity of the voluntary discharge of the torpedo, the manner in which the waves composing it succeed each other and are added together, forms a very important confirmation of the numerous presumptions already made.

\section{FRANCOIS FRANCK}

\section{SCIENCE IN LANCASHIRE AND CHESHIRE}

$A T$ Liverpool the annual associated soirée of the Literary, Scientific, and Art Societies, eighteen in number, of which twelve are scientific, held at St. George's Hall on the 31st, was a marked success, and will tend much not only to foster scientific tastes in this district, but inculcate an element of scientific cooperation, in the various institutions of the town, that will be of the highest practical value. The fourteenth Winter Course of Free Lectures for the People, given at the Free Library and Museum, by order of the Corporation, commenced on the 6th of last month. Amongst the forty-one lectures announced, thirteen are on scientific subjects, given by the Rev. W. H. Dallinger, Mr. Moore (Curator), Mr. De Rance, Rev. H. H. Higgins, and others. The Liverpool Geological Saciety is also doing good work; a valuable paper on the carboniferous limestone of Denbighshire was lately read by Mr. Morton, and a short but important mineraIogical paper was given by the President, Mr. Semmons. Geological knowledge has been increased by a boring at Bootle, sunk to determine the water-bearing properties of the new red sandstone at great depths, by Messrs. Mather and Platt, for the Liverpool Corporation, who were urged to this course by Alderman Bennett. The boring has reached a depth of 1,300 feet, is 25 inches in diameter, is filled with water up to a height of 50 feet from the surface, and, according to Messrs. De Rance and Morton, has proved the pebble beds of the Bunter to reach the extraordinary thickness of $x, 200$ feet, and the existence of the lower mottled sandstone beneath. The pumps not yet being fixed, it is impossible to judge how far the well will add to the supply of $6,000,000$ gallons a day at present pumped from the corporation wells.

At Wigan, in addition to the ordinary course of lectures given at the Mining and Mechanical School, a special course has been arranged for candidates for colliery managers' certificates, and gives to the teaching of the school a special technical direction. The extension scheme for turning the very numerously attended evening classes of this school into a Mining Collegiate Centre for Lancashire, has necessarily languished under the unexampled and continued depression in the coal trade, though from the number and extent of the promised subscriptions and donations to the building-fund, there can be little doubt that, when better times again visit this country, this school will develop into an important centre of technical education. The town has lately had the good fortune to have presented to it a magnificent library, stored in a handsome building erected for the purpose, the former being the bequest of the late Mr. Winnard; the latter the gift of Mr. Thomas Taylor. The reference library is well stored with standard scientific works in all branches, and the selection reflects great credit on the industry and acumen of Mr. Gerrard Finch, barrister-at-law, who selected them, under the terms of the will. Some important works are of course conspicuous by their absence, but doubtless this will soon be remedied. The reference portion of this library will henceforth be opened on a Sunday to readers who have asked for special tickets, the extra cost of assistants being defrayed for three years by Mr. Taylor, the donor of the building.
This town has also now a flourishing Literary and Scientific Society, with Lord Lindsay as president; it is divided into botanical, microscopical, and other sections, at which papers are read by the members, and discussed, and, in addition, special lectures are given to the united sections; amongst those delivered have been "Spectrum Analysis," by Lord Lindsay, and "Local Geology," by Mr. de Rance: others are announced by Prof. McKenny Hughes and Prof. Rudler.

At Southport there is at present little done for fostering a taste for either technical or scientific education, but the very fine aquarium is maintained in great efficiency, the contents of the table tanks, to which we have previously referred, being especially beautiful.

At Preston, meetings of the Scientific Society have been numerously attended, and the president, Dr. Arminson, and others, do good microscopical work. The meetings are held at the Avenham Institution, which is well filled with scientific works, including the natural history library of a defunct Naturalists' Society, and it is a matter of regret that the town, in adopting the Free Libraries Act, should not have carried out an amalgamation scheme, instead of running a new and inefficient library in opposition to the existing useful and self-supporting institution. The Gilchrist Trust lecturers here and at Burnley have been listened to with much interest by large audiences; and at the latter place Prof. Boyd Dawkins has inoculated his hearers with his taste for cavehunting investigations, and searches bave been organised into the wild hills which fringe the county boundary of Lancashire and Yorkshire, and form the backbone of England, a district which for the most part appears to be above the level of the glacial sea deposits.

At Chester the flourishing Natural Science Society that looks back with pride to Kingsley, its founder, and forward with hope to its president, Prof. McKenny Hughes, is divided into several sections like a small British Association: The most noticeable paper read was one by $\mathrm{Mr}$. Shrubsole, on the Fenestellæ of the carboniferous limestone, which was an important and valuable contribution to our knowledge of this group, proving from perfect specimens that several supposed species are, in fact, portions of the same organism. General lectures have been given to the united sections by Prof. Judd and Mr. De Rance, who opened the winter session. The Society possesses a very good local museum, but unfortunately it is exbibited in the disused ball-room of an ancient hotel in an out-of-the-way part of the city, and is known to few of the scientific visitors of Chester, and is but seldom visited by the inbabitants. The collection would, however, form an admirable nucleus of a museum for teaching purposes, should the Corporation ever recognise the need of technical education in this town, and erect a building to hold a library, museum, and science and art schools by the side of their fine town hall. Towards filling museums of this class, great advantage would accrue if the duplicate specimens at the British and Jermyn Street Museums were either given, or allowed to circulate, in the same manner as the art treasures from South Kensington Mujeum. For valuable as are local collections for the scientific specialists, no one can doubt the importance of giving wide and varied knowledge to the general public, such as, perhaps, can only be imparted by the inspection of typical specimens of the natural and artificial products of all countries. Such a collection may be seen on a small scale in the admirable little niuseum at Castleton, in Derbyshire, formed by $\mathrm{Mr}$. Rooke Pennington, which at once furnishes the visitor with all that can be collected for forming a mental local picture of the past, and affords the inhabitants of the district an opportunity of knowing something of the world around them.

At Manchester the museum at Owens College now includes the entire collections of the Manchester Natural 
History Society and Manchester Geological Society, as well as a small typical collection originally belonging to the College and the complete mineralogical and metallurgical collections of the late David Forbes; the series are admirably arranged for the purposes of study. Prof. Boyd Dewkins is curator.

\section{A REAL TELEGRAPH}

A NEW invention of a real practical chaA racter, not a mere "paulo post futurum" invention like many we have heard of lately, has just been made by Mr. E. A. Cowper, the well-known mechanical engineer. It is a real telegraphic writing machine. The writer in London moves his pen, and simultaneously at Brighton another pen is moved, as though by a phantom hand, in precisely similar curves and motions. The writer writes in London, the ink marks in Brighton. We have seen this instrument at work, and its marvels are quite as startling as those of the telephone. The pen at the receiving end has all the appearance of being guided by a spirit hand. The apparatus is shortly to be made public before the Society of Telegraph Engineers. We give a facsimile of the writing produced by this telegraphic writing machine.

\section{GEOGRAPHICAL NOTES}

THE Spanish Ministry of Public Instruction has just issued a very important publication, being a collection of letters of Christopher Columbus, and of his contemporaries, as well as of reports sent in, during the sixteenth century by governors of the new American provinces, the originals of these letters and reports being now in the State Archives of Spain. The work, which bears the title "Cartas de India" (Letters from India), and forms a large volume of 877 folio pages, contains the following highly interesting documents: (I) Two autograph letters from $\mathrm{Co}$ lumbus, written in 1502 to King Ferdinand and Queen Isabella, the first letter dwelling upon the necessity of measures for increasing the population of the island "Española" (San Domingo), and the second being a discussion on the art of navigation; (2) a letter from Amerigo Vespuchi to the Cardinal Gimenes di Cuneros, Archbishop of Toledo, dated Sevilla, 1508, and dealing with the merchandise to be sent to the Antilles; (3) two letters from Fra Bartholomeo de las Casas, Archbishop of Nicaragua, to the Infanta Don Filippo, dated Gracias a Dios, in Guatcmala ; (4) two letters from. Bernaldo Diaz del Castillo, one of the warriors of the small army of Cortes, and author of a history of Mexico, to Charles the Fifth (1552), and to Philip the Second (1558); (5) letters from the baccalaureates Don Pedro de Gasca and Don Christophor Vaca de Castro, dated Quito, I54I and Cusco (1542), announcing to Charles the Fifth the death of the Marchese Don Pizaro and the insurrection of Don Diego de Almagro; both letters are very interesting, being accounts of eye-witnesses; (6) a very interesting letter of Donna Isabella Quivara to the Regent, Donna Huana, about the remark-

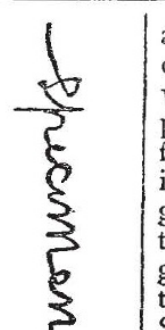

able courage displayed by women during the expedition of Cortes, when all male members of the expedition. were exhausted by disease. The work contains 652 pages of text and 225 pages of appendix, in which we find twenty-nine autograph letters and reports of various important historical persons ; twenty-one sheets of autographs of Columbus, Vespuchi, Las Casas, Diaz del Castillo, Gimenez, \&c. ; a map of the fortifications where the gems of the Incas were found; and maps of Australia, of the River Amazon, the Antilles Archipelago, and Magellan Strait, drawn in the sixteenth century. We are sure that all friends of historical geography will feel grateful to the Spanish Government for this valuable publication.

Col. PRJVAlsky has left St. Petersburg to make anothex trip in Central Asia. He will proceed by Orenburg, Omsk, and Semipalatinsk to the Chinese frontier, thence to Hami, Hansu and Lassa. From Lassa he intends to. reach the Himalaya by the Brahmapootra. Returning. then to Lassa, he will visit Khotan, Kashgar, and cross. the intervening plateaux to Russian Khokand. The journey is to occupy two years.

PÈre HORNER has addressed a letter, dated Zanzibar, December 12, to Les Missions Catholiques, announcing that the members of the German scientific expedition have returned in bad health. This expedition, under the command of Herr C. Denhardt, started from Melinda, and explored the course of the River Dana, which has hitherto been supposed to take its rise in the slopes of Mount Kenia. They experienced many difficulties, and did not succeed in getting more than about sixty miles into the interior. According to Père Horner's report, in the place of Mount Kenia, covered with snow, they found only plains, and though they questioned more than 200 persons on the subject, they could find no one who had heard of the mountain. Père Horner thinks that the German travellers have not been far enough into the interior, and he says that they are going back again shortly to solve the problem. The truth, however, we believe is that Herr Denhardt has found that the Dana has. a widely different course from that generally assigned to. it, and that it does not flow anywhere near Mount.Kenia. The party obtained a very complete series of meteorological observations, and they report that at some distance from the coast they met with a quiet and industrious tribe called the Vakopomo, who, it is thought, would welcome missionaries among them, if the fanatic Somalis of the coast region would allow them to pass.

In the February number of the Geographical Society's new periodical we find a curious and learned paper by Sir Henry Rawlinson, entitled "Rough Notes on Prehistoric Cyprus, and another on the "Upper Basin of the Kabul River," from Mr. Markham's versatile pen, accompanied by a carefully drawn map of the Hindu Kush. Some of the geographical notes are of considerable interest. A St. Petersburg correspondent reports finding Prjvalsky restored to his habitual vigorous state of health and busy preparing for his next expedition, in which he hopes to reach Lhassa by the Hami and Sha-chau road, accompanied by young Eklon. Prjvalsky's Lob-Nor plantcollection turns out to be not very rich, the number of species being exceedingly few. Under the beading "Explorations North of India," we have the leading features of an unpublished report by Capt. Woodthorpe, R.E., and Lieut. Harman, of their recent work in the unexplored Miri and Mishmi Hills. In the latter region Capt. Woodthorpe obtained a fairly accurate knowledge of the sources of the Dihong River and the course of its main stream in the bills. The result of these explorations proves that the volum of the Subansiri is only one-fourth of that of the Dihong, which tends more than ever to identify the latter with the great river of Thibet. Some particulars are also furnished respecting the Dar-es-Salaam road in East Africa. 